\title{
Mechanisms for enhancing employer investment in training: a comparative perspective
}

Andrew Smith (Charles Sturt University) and Stephen Billett (Griffith University)

\begin{abstract}
In recent years, the debate over reform to national vocational education and training systems has shifted from a focus on the supply-side of VET - qualifications structures, national training schemes and institutional structures - to demand for training by industry and the role of employers in increasing the skills levels of the workforce. Yet, enhancing employer demands for training has proved to be a perennial problem for governments of all political complexions in the developed world. Approaches to securing enterprise investment in training by governments form a continuum from low-level intervention to compulsion and regulation, and range from approaches which attempt to secure voluntary commitment through to legislating enterprise expenditure on training (Billet \& Smith 2005). Voluntary commitment is often seen as the most desirable and self-sustaining approach, but is difficult to secure from enterprises. As a result, governments have often experimented with policies of compulsion to make employers invest in training such as training levies. However, decisions about expenditure on training ultimately depend on individual employer's interests, values and commitments. Improving and enhancing employers' perceptions of the value of training are vital to increasing the levels of expenditure. This paper discusses the range of government approaches to encouraging employers to invest in training and development that are to be found in the developed world. It argues that compulsory employer levies are rarely successful and that increasing the level of investment in training by employers is more likely to be achieved through more subtle policy mechanisms.
\end{abstract}

\section{Introduction}

There is a multiplicity of arrangements that have been used worldwide to increase employer investment in training. As Keating et al (2002) remark, most developed economies have been wrestling with the issue of demand management in enterprise training for many years and none has yet developed the perfect solution:

It is in this area that the ideological divides are the most prominent, exemplified by the UK on the one hand with its voluntarist traditions and France on the other with its high degree of state intervention. (Keating et al, 2002:171).

One could add to this, those national arrangements for the financing of employer training are also heavily influenced by these nation's economic and social structures. This means that although national approaches have tended to be uniquely developed to suit their economic, social and cultural circumstances, there are common elements between them partly based on shared cultural and social values. Therefore, it is possible to identify some commonalities in policies approaches across these economies. Indeed, Gasskov 
(2001) developed a typology of government -employer-financing arrangements for training. He identifies five different approaches:

1. Enterprises have no legal obligations for training (e.g. Canada, UK, USA, the Netherlands and Sweden)

2. Employers voluntarily take significant responsibility for the financing of training (e.g. Germany, Switzerland and Japan)

3. Employers and unions set up training development funds under collective industrial agreements (e.g. Belgium, Denmark and the Netherlands)

4. Government offer tax exemptions to enterprises that train their workers (e.g. Belgium, Chile, Germany, South Korea, Malaysia and Pakistan)

5. Governments introduce compulsory financing of training by employers (e.g. Denmark, France, Ireland, South Korea, Malaysia and many South American countries).

Others have developed typologies more explicitly based on the social, economic and cultural differences between nations. Ashton and his colleagues at the Centre for Labour Market Studies at Leicester University developed a framework to explain skills formation practices in a variety of nation states (Ashton et al, 2000). They identified four models of skills formation: market; coporatist; development state; and neo-market models. In the 'market model' employers were left to decide on the type and amount of training that they provided to workers. Countries using the market model were claimed to include Australia and New Zealand apart from the UK and the USA.

The 'corporatist model' developed in northern European countries that industrialised at the end of the $19^{\text {th }}$ century. In these countries governments encouraged the development of more collaborative systems of industrial relations with between employers and their labour movements. These collaborative arrangements also applied in the area of training with its modern manifestation in the role of the social partners in training in the German, Austrian and Swiss dual systems and the training funds of the Scandinavian countries. The 'developmental state model' arose in those East Asian countries that have achieved high levels of growth in the post-war world. Included here are Japan, South Korea, Singapore and Taiwan. Governments in these countries also consciously moulded the education and training systems to provide the skills for rapid industrialisation. Finally the 'neo-market model' was founded on the rapid state-led industrialisation of the economy often found in Latin America that was nevertheless unbalanced in that the development of financial institutions did not keep pace with the level of industrialisation. However, the collapse of these economies in the 1980s and 1990s led to the intervention of financial bodies such as the International Monetary Fund and the imposition of free market economic policies in those countries. The result of these policies was the decentralisation of the provision of education and skills training with the growth of a significant private sector.

For the purposes of this project, we synthesised these typologies of government-employer financing arrangements in order to categories the various mechanisms that have developed world-wide to encourage greater employer investments in training in a way that has particular meaning in Australia. Our categorisation is as follows: 
1. Laissez-faire systems.

2. High employer commitment systems.

3. Sectoral training funds.

4. Levy Schemes.

Having identified some models of approaches to enterprise investment in training, the section that follows identifies something of the policy mechanisms that have been adopted within these models.

\section{Laissez-faire systems}

These systems apply in countries covered by Ashton et al's market model - Australia, the UK, the USA and Canada. In these systems there are few regulations imposed on employer training activities. Employers are free to train or not in accordance with their perceived business needs. The laissez-faire approach has attracted much criticism in all these countries that have been famously characterised as tending to a low-skill equilibrium (Finegold and Soskice, 1988) in which the need for skills is replaced by work simplification and deskilling in a mass production environment. More modern commentary has tended to repeat this theme, viewing the persistence of skills shortages in these countries as proof of market failure in training (Hall, Buchanan and Considine, 2002; Ashton and Green, 1996).

In the UK the laissez-faire approach is typified by The Investors in People (IiP) program that operates in a similar fashion to I in full SO accreditation in the area of quality management, but with a specific focus on human resource development practices in enterprises. Those enterprises meeting the IiP standard are permitted to use the IiP kitemark for publicity. Although slow to gain ground, in recent years the IiP program has expanded quite rapidly. Since 1999, the number of enterprises recognised under IiP has more than doubled from 13,748 to reach 37,035 in late 2004 and the percentage of the workforce covered by the IiP standard has increased from 15.5 per cent to 38 per cent over the same period (www.iipuk.co.uk). However, the take up of this initiative uneven, being concentrated amongst large and, to a lesser extent, medium sized firms. In a survey conducted for the Department for Employment and Education in 2000, only 16 per cent of UK firms had been formally recognised in IiP (DfEE, 2001). Table 1 show that recognition is also concentrated in certain industry sectors - particularly the public sector. The skewed distribution of IiP recognition by size and industry, however, reflects the skewed distribution of training to be found in most developed countries and suggests that IiP has achieved little in the improvement of access to training.

Table 1

Recognition in IiP by industry sector of employer

\begin{tabular}{lc}
\hline Industry sector & \% recognised \\
\hline Manufacturing & 10 \\
Agriculture, mining and utilities and construction & 8 \\
\hline
\end{tabular}




\begin{tabular}{ll}
\hline Distribution \& consumer services & 19 \\
Finance and business services & 14 \\
Transport, public admin \& other services & 21 \\
\hline TOTAL & 16 \\
\hline
\end{tabular}

Source: DfEE (2001:94)

This skewed distribution of training amongst enterprises and has led commentators to remark that IiP has been used to highlight those enterprises that already invest significantly in training, rather than encouraging firms that do not invest to undertake more training of their employees (Hoque et al, 2005). Amongst enterprises that are involved with IiP, the scheme seems to have a beneficial impact on the nature and quality of the training they undertake. An evaluation of IiP for the Institute of Employment Studies concluded that IiP had:

- Spurred employers to make changes to existing practices that would not have otherwise occurred;

- Delivered improved training and skills that enhance business performance; and

- Added value to the enterprise above the costs of the scheme (Hillage and Moralee, 1996).

IiP appears to work in a similar fashion to ISO and other forms of quality accreditation it improves internal processes for those already providing training, but it is not clear that it increases overall employer investments (Emberson and Winters, 2000). It is easy to see how critics might conclude that in liberal and weakly regulated economies, that companies might seek to engage in programs for their strategic purposes, rather than a broader societal concern about skilling.

\section{High employer commitment systems.}

These systems occur in those countries covered by Gasskov's category of systems in which employers voluntarily take a high degree of responsibility for skill formation. There is legal obligation on employers to train but the training systems are based on workplace-based training financed by employers.

In Germany, the famous "dual system” is focused on initial vocational training (IVT) providing large scale apprenticeship training across most sectors of commerce and industry. Responsibility for the operation of the dual system is agreed between the federal government, the state (lander) governments and employers through their associations - the regional chambers of commerce and craft. In this arrangement, the employers play the dominant role. The federal government brokers the relationship between the social partners and the system is founded on the federal Vocational Training Act passed in 1969 that defined the role that the parties play in the system. State governments or Lander provide the vocational training schools that provide the off-thejob instruction in the apprenticeship system. 
However, employers provide the bulk of the funding for the dual system through the Chambers of Commerce and the Craft Chambers. It has estimated that over 70 per cent of the funding of the dual system is provided in this way by employers. Employers contribute to the system through payments made to the chambers by those firms that employ apprentices. However, in recent years that dual system has come under strain as employers seek to meet the demand for places that has been increased by the absorption of the former East Germany into the federal republic. In essence, there are fewer training places offered by fewer employers. It has also proved difficult to persuade former East German employers to take part in the dual system because there was no tradition of employer sponsored training under the communist regime (Cockerill and Scott, 1997). However, in recent years fewer employers in the former West have taken on apprentices as a result of the on-going economic problems of the country. Other problems that have been highlighted in recent years in the dual system include:

- A perceived lack of flexibility to accommodate new and emerging occupations. The dual system appears to be slow moving and cumbersome in its recognition of new occupations or changes to existing occupational knowledge. However, it appears that the system is becoming more responsive to occupational change and the BIBB is concerned to ensure that quality training standards are put in place for new occupations (Sauter and Schmidt, 2002).

- A push by employers to reduce the length and timeserving nature of apprenticeships. Concerned by the increasing number of young people who are choosing the higher education pathway through the academic high schools (Gymnasia) and the university entrance qualification (abitur) over the traditional apprenticeship system as well as the 10 per cent of young people who drop out of the system, employers have suggested that new 2 year apprenticeships be introduced to combat the drift away from the system.

However, employer financial commitment to IVT in the dual system does not translate into a similar commitment to continuing vocational training ( CVT). Perhaps surprisingly given their commitment to entery level training, at only 0.9 and 0.8 per cent of payroll respectively, Germany and Austria are amongst the lower spending countries on CVT in the EU. CVT is largely unregulated in Germany and is viewed as an individual expense. Hence, skilled workers wishing to obtain the "Meister" qualification largely do so in their own time and at their own expense. This is despite the fact that German enterprises cannot employ apprentices under the dual system without having a suitable number of meister on staff (Pischke, 2000). German unions have proposed that a levy be introduced on employers to finance CVT but his has been strenuously opposed by the employer organisations (Cockrill and Scott, 1997). Although participation in CVT is generally high in Germany at around 84 per cent (Giraud, 2002), individuals rather than employers finance much of this training. It seems that in the dual system countries, high employer investments in IVT are traded off against lower investments in CVT.

Denmark offers a different perspective on higher employer commitment to training. In this case, employer commitment to the training system is based on a combination of 
government financing and the role of the social partners in engineering consensus at the firm level on the importance of training. The Danish system of VET was traditionally based on a strong apprenticeship system. Unlike the German dual system, however, the Danish apprenticeship system was based on government regulation and financing of vocational training in a limited number of skilled trades. In the 1960s, as Denmark moved into a more industrialised economy, the popularity of apprenticeships dropped as young people favoured higher education and employers sought to expand training for semiskilled workers. In the mid 1960s, the adult vocational training (AMU) system became the central feature of the Danish system of VET. Financed by government but regulated through joint government, union and employer committees, the AMU system provides work introduction courses for young people and the unemployed, as well as training for semi-skilled and skilled workers (Olesen, 1997). AMU provides training for existing workers as well as for new entrants to the labour market and the unemployed. It is an integrated system that is aimed at the continuing vocational training needs of employers (employees?) as much as at the needs of new workers and the unemployed. AMU training is financed by government that pays the wages of those attending training in AMU programs and is delivered through a series of AMU colleges in Denmark (Nielson and Cort, 1999). The training programs offered through AMU are determined by the training plans drawn up for the 55 main industry and commercial sectors on the Danish economy and the emphasis throughout the system is on joint regulation by the social partners.

The notion of joint regulation operates very strongly at the firm level with the inclusion of training provisions in most collective agreements between employers and unions. Since 1991, many collective agreements have included the creation of training funds to finance employees' continuing training at both the sectoral and the individual firm level and the right to one week training level per year for a large number of employees. Much of the CVT offered by Danish employers is firm specific and provided through the AMU system (Olesen, 1997). It is estimated that about one third of the private sector workforce is covered by these collective provisions for training. However, the training funds in Denmark are not large. They operate on a tripartite basis, yet tend to fund only experimental and innovative training approaches.

A particular innovation in Denmark has been the Jobrotation system. This scheme involves the substitution of unemployed workers for workers in firms who are receiving training - usually through the AMU system (Nielsen and Cort, 1999). Although Jobrotation is usually spoken of as a training system, the scheme was devised as an answer to the very high levels of unemployment experienced by Denmark in the early 1990s. In 1993, when the scheme was first launched, the Danish unemployment rate stood at 12 per cent. Since that time, unemployment has dropped to around 6 per cent, although there are many other factors that the Jobrotation scheme that have contributed to this decline (Grunewald and Sorensen, 2002). Thus, Jobrotation is a combined work and learning program. Under the model, employers can seek funding form various government agencies to employ an unemployed person to replace a worker that is released for training. The usual ratio of workers for replacements is from 2 to 4 to one this the employer will release up to 4 workers for each replacement worker than can be funded. The advantage to employers is that they can train workers without any 
consequent loss of production whilst the replacement worker gains valuable work experience. In many cases, participation in Jobrotation has resulted in the creation of permanent jobs for the replacement workers (Grunewald and Sorensen, 2002).

Participation in Jobrotation expanded rapidly in the early years of the scheme to around 36,500 in 1996 or 1.3 per cent of the workforce. However, these rates of participation have declined as unemployment has dropped in Denmark. At the same time, employers have increased the ratio of training workers to replacement workers towards the 1:4 end of the spectrum. However, the model has been so successful in Denmark, that it has also been piloted in most of the European Union countries, particularly in Germany where unemployment remains high by OECD standards. The model suits the particular Danish concern with equity, consensus and skills development.

In the other Scandinavian countries of Norway and Finland, governments have not adopted specific policies on employer training. Both countries report a high level of employer training through the European Union's Continuous Vocational Training Survey. In Finland, 82 pert cent of employers provided training in 1999, whereas in Norway the figure was 86 per cent. Moreover, employee participation in employer provided training is high across small, medium and large firms with over 50 per cent participation by workers in training in small and large firms and slightly less in medium sized firms. These participation rates compare with an average of 40 per cent for the European Union countries as a whole (Nestler and Kaillis, 2002b). As a result of this high ongoing commitment to employer training, the Norwegian and Finnish governments have focused on other aspects of working life. Both countries have long sponsored research and innovation in the general quality of working life. Norwegian firms have also been pioneers in the introduction of autonomous team work and in the provision of employee benefits such as family friendly workplaces for a number of years. In Finland, the Working Life Development Program has emphasised the importance of high quality training and development program focussing on more productive workplaces. Thus, training plays a major role in the quality of working life programs that operate in both countries. However, the emphasis in these programs is not so much on the quality of employer training rather than on the quality of the training provided and the equality of access enjoyed by different groups - moving away from the skewed distribution of employer training found in all developed countries to a more egalitarian model. Employers in both countries also have access to funds provided under the Social Program of the European Union which provide support for improving aspects on working life, including the provision of employer training. In general, the consensus model that exists in both countries has encouraged the development of a widely recognised right to employer training amongst both employers and employees which underpins the high level of training provision.

The common quality of these schemes is that they are tolerated by a social sentiment that views the kinds of demands they make as being socially just. However, this may not be an option in countries adoptinga more liberal or laissaz faire approach.

\section{Sectoral Training Funds.}


Based on Gasskov's category of arrangements whereby employers and/or government establish training funds based on industrial agreements between the social partners and Ashton's corporatists model, sectoral training funds cover industry sectors and allow employers to provide training with funding provided by the training funds.

The Netherlands provides the clearest example of the application of sectoral training funds nationally. In the early 1980s, the Netherlands adopted the "Polder" model of employment regulation. This model derived from a national agreement on wage fixing which saw the end of automatic indexation in return for return for a commitment on the part of employers to bargain on working hours (Wassenaar Agreement). The model of social partnership established in the Wassenaar Agreement became the basis for many other aspects of employment regulation in subsequent years (Mulder and Tjepkema, 1999).

Following the principles of the Polder model, the Wagner Commission in 1984 recommended that the VET system should be administered through a social partnership arrangement involving government, training providers and the business community. Since that time, the VET system has been regulated through a series of tripartite committees. From the tripartite approach grew the concept of sectoral training funds established under collective industrial agreements in all the major sectors of the economy. These Training Research and Development Funds (known by their Dutch acronym as $\mathrm{O}+\mathrm{O}$ Funds) have become the principal route for introducing social partnership arrangements into an area of activity that is normally the preserved of employers (Romijn, 1999). There are some $66 \mathrm{O}+\mathrm{O}$ funds operating in the Netherlands under 134 Collective Agreements. Most of the collective agreements also specify other training provisions, particularly with reference to on-the-job training and training for target groups in the workforce. The $\mathrm{O}+\mathrm{O}$ funds are managed by collective bodies with employer and union representation. The funds are based on levies of all firms covered by the collective agreement under which the fund is established. The levies vary by sector and range from 0.1 to 0.7 per cent of gross wages. Although there are no uniform rules by which the $\mathrm{O}+\mathrm{O}$ funds are administered, there are three main ways in which funds tend to expended (Waterreus, 1997):

- Awarding collective training days for a certain sector. In this case employers in the sector can bid for funds to support a number of training days which the employer then allocates amongst employees;

- The awarding of individual training days. This provision finances individual training leave and can be taken at the employee's discretion.

- Awarding funds to support training programs detailed in training plans submitted by employers. The fund may support up to 50 per cent of the costs of a training program.

Thus, the $\mathrm{O}+\mathrm{O}$ funds are an expression of the collective regulation of CVT in the Netherlands. However, it is important not to overstate their importance in the financing of CVT. The firms themselves provide the bulk of funding for CVT in Dutch firms. In 1996, the O+O funds only accounted for less than 5 per cent of the total private 
expenditure on CVT. Funding from employers accounted for over 50 per cent of expenditure on CVT with individual expenditure accounting for the balance (Hendriks and Westerhuis, 1997). Not all the funds placed in the $\mathrm{O}+\mathrm{O}$ funds are spent on training, as administration costs sometimes consume a portion of the funds. . The proportion spent directly on training varies from 5 per cent to 100 percent. However, overall Waterrreus (1997) estimated that an average of only 40 per cent of $\mathrm{O}+\mathrm{O}$ funds are allocated directly to training.

The principal example in Australia of this approach is the construction industry training fund which is operated in a number of states albeit in different forms. The construction industry training funds are much smaller than their Dutch equivalents and are typically funded by a levy of around 0.1-0.2 per cent on building value. In many cases, these funds have been used to support apprenticeships in the industry and have not been used widely for CVT. It is difficult to argue that the construction industry levy has been very successful in raising training expenditure in that sector when repeated surveys have shown that employers in construction consistently spend less on training than employers in most other sectors (ABS, 2003).

In Victoria, the Victorian Brick and Blocklaying Training Foundation (VBBTF) has been formed by the Clay Brick and Paving Association of Victoria with the Housing Industry Association and Holmesglen Institute of TAFE. From 1 July 2003, a levy of \$1 will be charged to consumers on every lot of 1,000 bricks sold for domestic purposes, manufacturing members of the VBBTF will match the levy dollar for dollar to create a training fund estimated at $\$ 1$ million per annum. The levy is being introduced to help address the shortage of skilled brick layers in Victoria and which is causing serious delays in domestic construction. The Training Fund will be used to fund preapprenticeship training, subsidise apprentice bricklayer costs and promote the industry. However, it should be noted here that the levy is paid directly by consumers purchasing bricks.

So in these schemes, sectoral interests play out and need to be engaged to secure positive outcomes for participating sectoral partners.

\section{Levy schemes.}

Gasskov's category of the compulsory financing of training by employers is found mainly in Ashton's corporatist and developmental state models, although examples of such schemes exists outside these countries such as the now defunct UK levy-grant scheme. The most commonly quoted means of increasing employer investments in training are universal levy schemes in which all or most employers are required to pay into a training fund from which they can apply for funding to support training (i.e. levygrant systems) or pay into a fund if they do not meet a pre-determined level of training expenditure (levy-exemption systems).

The most widely quoted example of levy systems is the French scheme. In fact, the French system is not a single integrated levy scheme but a series of levy schemes that have developed since the 1920s and which finance different aspects of the IVT and CVT 
provision of French firms. For this reason, the scheme has often been viewed as unnecessarily complex and possibly ineffective, certainly if measured against the skill formation system of Germany which does not operate a comparable levy system (Giraud, 2002). Since 1925, French firms have been obliged to pay an apprenticeship tax of 0.5 per cent of wages and salaries. The tax was originally intended to pay for a variety of training activities other than apprenticeship. However, since 1971 through reforms to the financing of VET in France, the tax has become focused on IVT (Bertrand, 1993). All French firms are liable to pay the apprenticeship tax except those firms that already employ apprentices. At least 40 per cent of the tax must be allocated to apprenticeship training, but the remainder may be used to finance other training institutions (Keating et al, 2002).

Since the 1971 Further Training Act was legislated French firms are also obliged to spend 1.5 per cent of their wages and salaries bill on further training activities or pay the equivalent into funds set up for this purpose. This act also established the right of the individual to personal training leave and established bi-partite mechanisms at the regional and industry level to manage the training funds created through the operation of the levy. The funds are collected from firms through agencies working for the Ministry of Labour that oversees the scheme known as the Organismes Paritaires Collecteurs Agrees. The funds are paid into over 100 local and industry based training funds where they are managed by joint union-employer committees (Brochier and Meiaux, 1997 cited in Giraud, 2002). In practice, however, employer associations tend to jealously guard their right to manage funds contributed by their members. The levy is spilt into 4 different elements:

0.1 per cent finances the right to individual training leave;

0.1 per cent goes to financing training that is a "balance" of individual and firm requirements;

0.4 per cent goes to funding non-apprenticeship "alternance” training, often sandwich courses in practice; and 0.9 per cent to the training of the existing workforce.

The levy applies to all firms employing more than 10 workers. Firms employing fewer than 10 workers pay an overall 0.25 per cent of wages and salaries as their levy. The French levy system is clearly convoluted and contested. Nor is it clear that the operation of the levy has led to a better system of CVT. As Goux and Maurin (2000) point out, access to training for French workers is as restricted as in other European countries (and Australia) to the already educated and professional groups. Neither has the French levy system necessarily led to better CVT outcomes. (Andrew - some support for this claim here?) French enterprise expenditure on training remains at 2.4 per cent, lower than the UK that does not operate any levy system (Giraud, 2002). Participation in CVT in France is around 58 per cent, considerably lower than that in Germany with little regulation of CVT and access to CVT remains highly skewed towards the well-educated, professional groups and those working in large enterprises. Training is often viewed as a perk or reward for performance rather than undertaken to meet the strategic needs of 
firms (Giraud, 2002). Similar criticisms were made of the Australian Training Guarantee at the time of its operation.

In Australia, the Training Guarantee Scheme (TGS) was a form of levy-exemption scheme. The TGS was not strictly a levy. Enterprises with payrolls in excess of $\$ 200,000$ were required under the Act to spend at least 1.5 per cent of their payroll costs on eligible training or pay the shortfall to the Australian Taxation Office. Eligible training was defined as structured and employment-related. Specifically this meant that training must be part of a recognisable program that was employment -related. Both onthe-job and off-the-job training were eligible under the TGS. The arguments that were advanced by the federal government in support of the introduction of the TGS emphasised the need for a highly trained workforce in the restructuring of Australian industry that accompanied the reform of industrial relations under the award restructuring movement. Overseas countries such as Singapore and Korea were quoted as examples of the successful implementation of levy based interventions in the training market (Dawkins, 1988). Unlike the French schemes ther was graduated contributions for smaler employers who were exempt from making contributions under the TGS.

However, the TGS proved unpopular with Australian employers. A key criticism made by employer groups was the compliance costs of the TGS were excessive. Research by Velten (1990) showed that many enterprises considered that the costs of keeping records and ensuring that all eligible training was reported far outweighed the cost of paying the levy. Smaller businesses, in particular, expressed this view and there was a widespread belief that many smaller enterprises simply paid the levy rather than incur the costs associated with training. The TGS was also attacked for its focus on the quantity rather than the quality of training (Noone, 1991) and for instituting a regime based on punishment for non-compliance, rather than rewarding enterprises that increased their commitment to training.

Nevertheless, advocates of the TGS were able to demonstrate some positive effects. Teicher (1995) identifies three such effects. First, the requirement to record the training that took place in an enterprise led to greater level of accountability for managers in providing the requisite training for employees. Second, the availability of more information on training activities in the enterprise allowed managers to evaluate the effectiveness of training more closely. Finally, the TGS raised the status of training within enterprises, so that managers were able to take a more strategic approach to the linking of training activities with the business needs of the enterprise. However, little firm evidence has been produced that the TGS played a significant role in the increase in training expenditure from 1990 to 1993 (Baker, 1994) or that its suspension in 1994 led to the decrease noted in the ABS data from 1993 to 1996. A number of interviewees in this study also expressed some support for the aims and objectives of the TGS. In general, the TGS was viewed as having suffered from bad image - the emphasis on rorts in the popular press towards the end of its life - and the widespread perception of the punitive nature of the arrangements, particularly as it was administered through the Australian Tax Office (ATO): the federal governments taxation department. Nevertheless, it was felt by some interviewees that the TGS had promoted the issue of 
training onto senior management and Board agendas effectively and that the system might have been better reformed rather than abolished.

A more successful application of the levy principle and one that explicitly addresses the issue of equity in access to training opportunities, is to be found in Singapore. As the many studies by Ashton and his colleagues at the Centre for Labour Market Studies in the UK have shown (Ashton and Green, 1996, Ashton and Sung, 1997, Ashton et al, 2002), Singapore has based its economic development since independence from Malaysia in 1965 on a planned approach. In this planning process, manpower planning has played an explicit role and early on the significance of education and training to the economic prosperity of the city-state was recognised (Goh, 1961). As a result, Singapore has developed a multi-departmental and tripartite approach to skill formation (Osman-Gani and Tan, 2000). This approach has involved the establishment of government bodies such as the National Manpower Council that directs the development of the education system on the basis of manpower forecasts developed by the Ministry of Trade and Industry. As a result, Singapore adapted its highly competitive education and training system to the requirements of government plans for industrialisation in the 1970s and latterly the move to higher value-added manufacturing in the 1980s and innovation in the 1990s.

However, a significant problem in Singapore since independence has been the existence of many unskilled and lower skilled workers concentrated in certain areas of the economy. As Singapore's economy has traditionally grown on the back of substantial foreign direct investment, the problem faced by the Singaporean government has been to encourage foreign owned multinationals to invest in the training and development of their workers to complement the efforts the government has made to modernise the education and training system (Ashton et al, 2002). In order to encourage employer investment in the training and development of low skilled and low wage workers, Singapore enacted the Skills Development Fund in 1982. This fund is administered on a tripartite basis by the Productivity and Standards Board, the Singapore National Employers Federation and the National Council of Trade Unions. Employers are obliged to contribute a Skills Development Levy of 1 per cent of the salary of workers they employ earning less than S\$1500 per month or S\$2, whichever is the greater. This ceiling has been raised since the inception of the scheme in order to bring more workers into the scheme (Low, 1998).

Employers and employees can recover the costs of taking approved programs under the scheme. These approved programs have usually been aimed at improving the overall educational level of workers rather than at providing specific skills. Thus, the most common programs undertaken under the SDF have included the Basic Education for Skills Training (BEST) program aimed at bringing workers up to primary school leaving levels of education. A further scheme, the Worker Improvement through Secondary Education (WISE) program, takes workers up to secondary school leaving standard of education (Osman-Gani and Tan, 2002). Other schemes that are financed under the SDF include the Training Plan Scheme which encourages employers to plan their training activities over a 12 month period and the Skills Certification Plan which is a proposal to train at leats one third of the firm's workers in certifiable skills over a three year period 
(Ministry of Manpower, 2003). Thus, the SDF has been focused on raising the general level of education amongst Singaporean workers who have not received the benefit of a full education. More recently, the scope of the SDF has been expanded to encompass specific skills programs particularly in the high tech areas of electronics and computing. The SDF funds have also been used increasingly to train older workers with one in eight older workers provided with an opportunity to train in 1995 compared to one in twentyfive in 1988 (Low, 1998).

There seems to be strong evidence that the highly targeted nature of the SDF levy has had a significant impact of the skill levels and training activities of Singapore. National investment in training amongst employers has reached 3.6 per cent of wages and salaries and the Singaporean government aims to push this up to 4 per cent (Low, 1998). The most productive industry sectors appear to be those, such as the computer manufacturing industry, that also account for the majority of training places under the SDF scheme. However, it has to be remembered that the SDF operates in a tightly regulated environment. Government has planned both the development of the economy and the education and training systems and Singaporean employers subscribe to the state vision for the future of Singapore. In these circumstances, employers willingly contribute to the SDF and are committed to the achievement of its aims - the development of the skills of under-educated workers.

So it seems that the more localised the levy schemes and possibly locally governed the more likely that enterprises will agree to contribute and support the scheme.

\section{Discussion}

As evidenced above, there have been a plethora of arrangements devised by governments to increase employer investment in training. Yet, most countries have struggled to manage the demand side of training and most training reform programs have been focused on improving the supply of training in the hope that employers will take advantage of new policies and increase their training effort. Changes to the supply side have included making public training institutions more responsive to employers' needs. This has formed a major part of the reforms to training undertaken in Australia and in the Netherlands (Brandsma, 2003). Other reforms have included the use of competencybased training, the introduction of new vocational qualifications frameworks and reforms to entry-level training. In general, changes to the supply side seem to have had little impact on employer investment levels. By contrast, government attempts to directly influence the level of investment in training by employers, as outlined in this paper, have been few and quite limited. Governments are in a much weaker position to influence the behaviour of employers directly. Employers form a major stakeholder in the polity and governments are often reluctant to attempt to regulate their behaviour for fear of jeopardising future investment in the country (quoted in Fenna date). For this reason, the policies adopted by governments have often been sporadic or involved the voluntary participation of employers. Where compulsion has been used such as the British levy- 
grant system of the 1960s and 70s or the Australian Training Guarantee, they have often been successfully resisted by employers.

For this reason, compulsory and universal levies to support training investment have not enjoyed a history of success. In Australia, the Training Guarantee Scheme (TGS) was imposed by the federal government on all except the smallest Australian enterprises. The TGS was introduced at the same time that the government was also introducing major reforms into the supply of training - the National Training Reform Agenda (Smith and Smith, 2005). It is interesting to note that the TGS was the only demand side policy adopted as part of the training reforms in Australia. Moreover, the training reforms were in general introduced through extensive processes of tri-partism and consultation (Cooney, 1997). This was not the case with the TGS which was imposed by Act of Parliament on a reluctant employer body. It is not surprising given the employer resistance and the compliant response that the TGS elicited that the scheme was abandoned within four years. In France, where a training levy system has been in place for a long period of time, employers enjoy a higher degree of control over the scheme because it is administered locally. Local funds are administered by the OPCAs under joint employer and union supervision. Here, employers have a far greater influence on the use of the training funds than Australian employers enjoyed over the TGS which was administered through the Australian Taxation Office. Yet, even in this employer controlled regime, it is not clear that the French levies have resulted in significant increases in employer investment in training. Data collected through the Continuing Vocational Training Survey in the European Union shows that French enterprises spend approximately 1.3 per cent of payroll costs on training activities (Nestler and Kaillis, 2002). This is about the mid-point for expenditure in the "older" EU countries - not as high as Denmark or the Netherlands who do not support a universal training levy. It is interesting to note that the last survey of employer training expenditure in Australia also established that Australian enterprises spend an average of 1.3 per cent of payroll on training (ABS, 2003), also without a training levy.

The two surveys used a very similar methodology allowing a valid comparison on this point. However, the Singaporean Skills Development Fund presents a counter-example to the argument against the efficacy of a universal training levy. Here, a strongly centralised state authority required all enterprises employing low skilled workers to contribute through a levy to the development of the skills base of the whole workforce. There is no doubt that this has increased employer expenditure on training, especially amongst low skilled workers. However, the context is different from that of the usual universal levy. Singapore is a small and highly cohesive state with a strong centralised government. The SDF is focused on a national requirement to increase the overall skills level of the workforce and enjoys a high degree of consensus. It appears that universal training levels tend to work only in very specific situations. It is noteworthy that the SDF model has not transplanted successfully into neighbouring Malaysia where political and social conditions more closely resemble other developed countries. This points to the particular culture and tight governance that comprises the Singapore state. 
Voluntary arrangements or arrangements that directly involve employers in the administration of training schemes appear to enjoy more support and be more effective in the long run. In the area of training levies, one of the reasons why the French system has endured longer than the British or Australian training levies has clearly been the decentralisation of the French levy administration to local industry training funds managed by joint union-employer bodies. These funds can directed to serve the particular training needs of local businesses and industry and have a tri-partite management structure. In this situation, employers may not enjoy paying a levy to fund training but they are in control of the process at a local level and can see the advantages that the training fund can bring. The sectoral training funds in the Netherlands provide a very good example of local administration and tri-partite control. Although the legislation for the Dutch $\mathrm{O}+\mathrm{O}$ funds formed part of the government's reforms to the VET system in the 1980s and the 1990s, the funds are administered through the industry-based collective bargaining arrangements that typify the industrial relations system in the Netherlands. The Dutch training levies are universal, yet are administered by the parties and are related strongly to the conditions of the industries within which they operate. In this case, local control is vested in each industry sector. Unlike the universal, centrally imposed levies of Britain and Australia, the $\mathrm{O}+\mathrm{O}$ funds have gained the commitment of employers and unions. A similar level of industry commitment is also present in the training levies that characterise the British and Australian construction industries. These sector specific levies have a long history in both countries and also operate in the construction industries in other countries such as Malaysia. Although the levies on employers in the construction industry are compulsory and universal, the funds are administered by independent bodies in which both unions and local employers are represented. Funds are channelled to meet the needs of local construction companies and members of the industry can see a direct relationship between the levy that they pay and the training opportunities that are funded.

Purely voluntary arrangements such as the Investors in People scheme in Britain enjoy a different form of commitment from employers. In this case, as in the case of the Baldridge Quality Awards in the USA or the Employer of the Year awards sponsored by the former Australian National Training Authority in Australia, the reward for employers is public recognition of their status as trainers of their workers. Although the effectiveness of such schemes in terms of improving employer investment in training has been questioned (Hoque et al 2005), they are popular worth employers. The growth in the numbers of employers recognised under IiP in Britain emphasises the value that British employers set by the scheme.

\section{Conclusion}

No country has yet developed a mechanism that has the desired impact of significantly raising employer demand for more highly trained workers. It appears that the effectiveness of mechanisms to increase employer investment in training depends critically on the relationship that employers have to the policies. Universal and compulsory levies are unlikely to elicit much employer commitment beyond a reluctant compliance with the schemes. Thus their likely impact on overall skills levels in the 
workforce is likely to be low. On the other hand, policies that involve employers in their formulation and implementation are far more likely to gain employer commitment. Whilst the overall effectiveness of such schemes to raise the overall level of workforce skills may be questioned, policies that gain active employer commitment are far more likely to have a positive impact on skills levies than those that do not. What has been proposed here is that beyond models and catregories of approaches tosecure greater investment in training by enterprises that local factors, policy traditions and the moments of history that countries find themselves in also shape the likeky efficacy of particular policy options. Attempting to create the more socially-engaged policies of northern European comutries in hardly realistic in countries that have different cultural values and are intolerant of the kinds of taxation atht such policies require. Certainly, the compulsion approach seems to have limited efficacy and is only likely in countries that have either a social charter that would tolerate these arrangements or a model of governance that is able to prosecute it.

\section{References}

Ashton, D and Green, F (1996). Education, training and the global economy. Cheltenham, Edward Elgar Publishing Limited.

Ashton, D. and Sung, J. (1997). Education, skill formation and economic development: the Singaporean approach in A.H. Halsey, H. Lauder, P. Brown and A.S. Wells (eds) Education: culture, economy and society. OUP, New York.

Ashton, D., Sung, J. and Turbin. (2000). Towards a framework for the comparative analysis of national systems of skill formation. International Journal of Training and Development , 4:1, 8-25.

Ashton, D. Green, F. Sung, J and James, D (2002) The evolution of education and training strategies in Singapore, Taiwan and S. Korea: a development model of skill formation. Journal of education and work 15:1 5-30

Australian Bureau of Statistics. (1997). Employer Training Expenditure Australia, July to September 1996. Canberra, AGPS.

Australian Bureau of Statistics (2003). Employer Training Expenditure and Practices, Australia. Canberra, AGPS.

Billett, S \& Smith, A (2005) Enhancing enterprise expenditure on VET: Policy goals and mechanisms. Journal of Vocational Education and Training 57 (1) 5-23.

Baker, M (1994). Training down under: an overview of the Australian experience in $\mathrm{R}$ McNabb and K Whitfield (eds) The market for training: international perspectives on theory, methodology and policy. Aldershot, Avebury.

Bertrand, O. (1993). Financial and fiscal devices to encourage the development of vocational training: $A$ case study of France. Unpublished. 
Brandsma, J. (2003). Seven years of reform in the Dutch VET system International Journal of Training Research. 1:1.

Cockrill, A. and Scott, P (1997). Vocational education and training in Germany: trends and issues. Journal of vocational education and training. 49:3, 337-350.

Cohn E \& Addison (1998) The Economic Returns to Lifelong Department for Education and Employment (DfEE) (2001). Learning and training at work 2000. London, DfEE.

Cooney, R (1997). The contingencies of partnership: experiences from the training reform agenda in Australian manufacturing. Employee Relations, 24:3. 321-334.

Dawkins, J. (1988). Industry Training in Australia: the need for change. Canberra: Australian Government Publishing Service.

Emberson, M. and Winters, J (2000). Investors in People: how a large public sector organisation in the UK dealt with a new national training initiative. International journal of training and development. 4:4. 259-271.

Fenna, A. (2004). Australian public policy, $2^{\text {nd }}$ edn. Sydney: Pearson.

Finegold, D and Soskice, D (1988). The failure of British training: analysis and prescription. Oxford review of economic policy, 4, 21-53.

Gasskov, V (2001). Government interventions in private financing of training. International Labour Organization, Geneva.

Giraud, O. (2002). Firms’ further training practices and social exclusion: can industrial relations systems provide greater equality? Theoretical and empirical evidence from Germany and France in K. Schoman and P.J. Connell (eds) Education, training and employment dynamics: transitional labour markets in the European

Goh, K.S. (1961). Differences in economic development problems as between Singapore and other Asian countries. Commerce (14). Nanyang University Commerce Society, Singapore.

Goux D \& Maurin E (2000) Returns on firm-provided training: Evidence from French worker-firm matched data (2000)

Grunewald, U and Sorensen, J.H (2002). Jobrotation as a new concept combining learning and work: German and Danish experience. Vocational Training European Journal. 24: 47-54.

Hall, R., Buchanan, J and Considine, G (2002). 'You value what you pay for': enhancing employers' contributions to skill formation and use: a discussion paper for the Dusseldorp Skills Forum Sydney: Dusseldorp Skills Forum.

Hendriks, L. and Westerhuis, A. (1997). Dutch vocational education: developments in initial and continuing vocational training. Den Bosch, CINOP.

Hillage, J and Moralee, J. (1996). The return on investors. Report 314. Brighton, Institute for Employment Studies.

Hills, K. and Ashton, D (1999). International briefing 2: training and development in the United Kingdom. International journal of training and development. 3:2. 167-179. 
Hoque, K., Taylor, S and Bell, E. (2005). Investors in people: market-led voluntarism in vocational education and training. British Journal of Industrial Relations, 43:1., 135-53.

Keating, J. Medrich, E., Volkoff, V. and Perry, J (2002). Comparative study of vocational education and training systems: national vocational education and training systems across three regions under pressure. Adelaide, NCVER.

Low, L. (1998). Jobs, technology and skills requirements in a globalized economy: Country study in Singapore. Geneva, ILO.

Ministry of Manpower (2003). http://www.gov.sg/MOM. Accessed 23 May 2003.

Mulder, M. and Tjepkema, s. (1999). Training and development in the Netherlands. International Journal of Training and Development. 2:1. 63-73.

Nestler, K and Kailis, E (2002). Continuing vocational training in enterprises in the European Union and Norway. Statistics in Focus, Eurostat.

Nielsen, S.P. and Cort, P. (1999). Vocational education and training in Denmark. Thessaloniki, CEDEFOP.

Noone, L (1991). Why I believe that the training guarantee is a great leap backwards rather than a small step in the right direction. Training and Development in Australia, 18, 19-20.

Olesen, K (1997). Denmark: the role of the social partners. Geneva, ILO.

Osman-Gani, A. A. and Tan, W. (2000). International briefing 7: training and development in Singapore. International journal of training and development. 4:4. 305323.

Pischke, J-S (2000). Continuous training in Germany. : IZA discussion paper; no. 137. University of Bonn. Institute for the Study of Labour (IZA)

Romijn, C. (1999). Financing of vocational education and training in the Netherlands: financing portrait.Thessaloniki, Greece: CEDEFOP.

Sauter, E and Schmidt, H (2002). Training standards in Germany: the development of new vocational education and training standards. Bonn, BIBB.

Smith, A and Smith, E (2005). Public policies on training and the effects of their provenance: An international comparison. Paper submitted to the 4th International Conference on Research in Work and Learning, University of Technology, Sydney. December 4-7.

Teicher, J. (1995). The training guarantee: a good idea gone wrong? in F Ferrier and C. Selby-Smith (eds) The economics of education and training 1995. Canberra, AGPS.

Velten, M (1990). Training guarantee scheme: Boon or burden? Australian Accountant, August, 26-9.

Waterreus, J.M. (1997). O+O fondsen onderzocht. Opelidings- en ontwikkelingsfondsen en de scholing van werknemers. Amsterdam. University of Amsterdam. 
